\title{
Not too small to benefit society: insights into perceived cultural ecosystem services of mountain lakes in the European Alps
}

\author{
Uta Schirpke $^{1,2}, \underline{\text { Rocco Scolozzi }}^{3,4}$ and Ulrike Tappeiner ${ }^{1,2}$
}

\begin{abstract}
Although the importance of lakes for providing cultural ecosystem services (CES) is widely recognized, the integration of associated values and benefits in decision making is still underdeveloped. Therefore, this study aimed at collecting and analyzing people's perceptions related to various CES of mountain lakes using an online questionnaire. We thereby distinguished societal values in terms of CES from individual experiences that contribute to subjective well-being and elicited perceived pressures reducing the quality of nature-based experiences. Based on 526 responses, our results indicate that bequest, symbolic, aesthetic, and spiritual values are perceived as most important, while representation and entertainment were less important. Accordingly, experiences such as connection to nature, relaxation, and freedom had the highest values. In terms of pressures, crowdedness was mentioned most often, followed by noisiness and garbage. These pressures mostly affected experiences such as connection to nature, freedom, relaxation, peace, and memories, with negative effects also on CES, mainly on aesthetic value, sense of place, existence value, and symbolic value. In general, the perceptions were highly consistent across different socio-cultural groups. Nevertheless, some differences emerged between groups with different cultural backgrounds with respect to CES and pressures, while differences in experiences were mostly related to gender. Our findings advance the understanding of CES related to mountain lakes and provide useful insights for research as well as decision and policy making, emphasizing the high intrinsic value expressed by the respondents as well as the variety of CES and experiences associated with mountain lakes. Moreover, the identified pressures provide a valuable basis for consideration in tourism management, the protection of natural resources, and sustainable development because they advance our understanding of how infrastructure development and socioeconomic changes may aggravate impacts on societal values and individual experiences.
\end{abstract}

Key Words: group differences; mountain regions; nature's contributions to people; perception survey; subjective well-being; trade-offs

\section{INTRODUCTION}

Lakes and reservoirs worldwide are highly important for human well-being. In addition to providing water for domestic and industrial use, irrigation, and hydropower production, as well as being important for flood control and climate regulation (Hogeboom et al. 2018, Ho and Goethals 2019, Sterner et al. 2020), they are highly valued for cultural ecosystem services (CES). Lakes provide, for example, opportunities for recreational activities, aesthetic experiences, education, and inspiration (Allan et al. 2015, Angradi et al. 2016, Reynaud and Lanzanova 2017, Fu et al. 2018, Hossu et al. 2019, Sterner et al. 2020). Large lakes are critical for sustaining human livelihood (Sterner et al. 2020) and are therefore the subject of a vast scientific and management literature. In contrast, small, and remote mountain lakes are highly appreciated for aesthetic experiences during hiking activities (Schirpke et al. 2021a, b), but such lakes are rarely included in management decisions, and the values that people associate with them and that may support developing sustainable management strategies are not yet sufficiently understood. Compared to other terrestrial ecosystems, small mountain lakes are more rapidly affected by climate change, posing a serious threat to lake organisms, ecological functions, and ecosystem services (Schmeller et al. 2018, Moser et al. 2019, Sadro et al. 2019). Increasing pressures on mountain lakes also originate from recreational use, livestock farming, and water extraction (Dokulil 2014, Van Colen et al. 2018, Brunner et al. 2019, Senetra et al. 2020). In particular, the importance of outdoor recreation and tourism is likely to increase in cooler regions such as the European Alps because of global warming (Pröbstl-Haider et al. 2021).
CES have been defined as the non-material benefits that are coproduced by human-ecosystem relationships (Chan et al. 2012, Fish et al. 2016). These benefits are mostly referred to as the values people obtain from their interactions with nature (Chan et al. 2012). Accordingly, various frameworks and common categorizations include CES relating to recreational, aesthetic, spiritual, symbolic, or cultural values (Haines-Young and Potschin 2018). CES have been related to different aspects of subjective well-being such as physical and mental health, identity, belonging, and inspiration (Russell et al. 2013, Bryce et al. 2016). Recently, blue spaces such as rivers, lakes, and coasts have been increasingly recognized for their salutogenic capacity (Völker and Kistemann 2011, White et al. 2013); indeed, they are considered to be "therapeutic landscapes" (Bell et al. 2018). However, research has mostly focused on coastal areas, whereas "freshwater blue-health,"i.e., the relationships between freshwater blue spaces and well-being, has received much less attention (McDougall et al. 2020).

The assessment of CES poses various conceptual and methodological difficulties, including unclear definitions and the challenge of separating services, values, and benefits, which are often strongly interwoven (Bieling et al. 2014, Hausmann et al. 2016). This can be explained by the fact that landscapes are experienced in a holistic way (Wartmann and Purves 2018), which makes it difficult to disentangle individual and collective associations (Muhar et al. 2018). Following recent literature (Kenter et al. 2015, Bryce et al. 2016, Fish et al. 2016, Muhar et al. 2018), this study therefore distinguishes between CES potential, representing societal values, and CES experiences,

${ }^{1}$ Institute for Alpine Environment, Eurac Research, ${ }^{2}$ Department of Ecology, University of Innsbruck, ${ }^{3}$ Department of Sociology and Social Research, University of Trento, ${ }^{4}$-skopia s.r.l. Anticipation Services ${ }^{\circledR}$ 
representing individual values related to subjective well-being. In particular, we understand CES potential as the capacity of mountain lakes to support activities and interactions of people with ecosystems (Chan et al. 2012, Fish et al. 2016), creating cultural values that are of societal importance (Kenter et al. 2015, Small et al. 2017, Muhar et al. 2018). We distinguish CES experiences that can be associated with a visit to mountain lakes by referring to different facets of subjective well-being (Russell et al. 2013, Bryce et al. 2016), which represent individual perceptions depending on personal preferences and values (Small et al. 2017, Muhar et al. 2018). In this way, we recognize the interactions between the individual level (CES experience) and the collective level (CES potential) in the perception and understanding of nature-human relationships (Muhar et al. 2018).

The subjective character of CES makes it difficult to quantify CES in biophysical or monetary terms (Daniel et al. 2012). Many studies have therefore applied non-monetary methods, including stated preference methods such as interviews, questionnaires, and participatory mapping methods, or revealed preference methods using social media data (Cheng et al. 2019). The analysis of social media data, e.g., photographs posted on online platforms, is relatively cost-efficient and can be applied for CES such as outdoor recreation at regional or cross-regional level (e.g., Angradi et al. 2018, Keeler et al. 2015, Oteros-Rozas et al. 2018). Insights from social media data are still limited because not all CES can be assessed without interviewing people and asking for their thoughts or feelings (Moreno-Llorca et al. 2020). Stated preference methods are often applied to elicit in-depth insights on CES, indicating a generally high agreement about preferences concerning the attributes of valued ecosystems or semi-natural contexts among respondents (Daniel et al. 2012). Some studies have also found that perception of CES can be influenced by the socio-cultural characteristics of the respondents (QuintasSoriano et al. 2018), i.e., perceptions can diverge because of different underlying values and belief systems (Muhar et al. 2018). For example, younger people prefer urban green spaces for social interactions, while older people appreciate more quiet naturebased recreational activities (Riechers et al. 2018), or females value CES provided by grassland more than males do (NowakOlejnik et al. 2020). Other studies have found some differences between local residents and visitors in terms of landscape preferences (Soliva et al. 2010, Zoderer et al. 2016a) or their connection or affinity with specific land-use types (Sayadi et al. 2009, van Zanten et al. 2016).

In summary, three major issues need to be addressed to better support the integration of CES into policies and management with regard to mountain lakes. First, to overcome conceptual issues related to CES (Plieninger et al. 2015), the distinction between community-based values and individual benefits may provide useful information for decision makers (Small et al. 2017). Second, knowledge about socio-cultural differences in perceptions can support the development of better-targeted management strategies. Finally, in contrast to large and low elevation lakes, small mountain lakes have rarely been the focus of CES assessments. Research on mountain lakes has mostly focused on ecological issues, but little is known about people's perceptions of the provided CES. Such knowledge is particularly important to develop sustainable management and conservation strategies considering the increasing impacts of global change on these sensitive ecosystems (Schmeller et al. 2018, Moser et al. 2019) as well as the increasing demand for outdoor recreation opportunities and nature-based tourism in mountain regions (Buckley et al. 2015, Pröbstl-Haider et al. 2021).

To address these challenges, we aimed to identify how people perceive CES of mountain lakes. Specifically, we aimed to (1) assess the variety of values people associate with these small ecosystems, distinguishing between CES potential (henceforth referred to as CES) and CES experiences (henceforth referred to as experiences); (2) recognize differences across socio-cultural groups; (3) identify positive and negative correlations among CES and experiences; and (4) assess the pressures on experiences. A better understanding of these issues may be helpful in managing the pressures on sensitive ecosystems and in anticipating potential conflicts between different user groups. Using a questionnaire, which was distributed to people living inside and outside the European Alps, we collected people's perceptions on CES, experiences, and pressures as well as socio-demographic information on the respondents.

\section{METHODS}

\section{Conceptual design}

The data for this analysis were derived from a questionnaire (Appendix 1) with closed and open-ended questions. The questionnaire included five sections, which were shown on separate pages:

- The first section started with a short description of the study's purpose and provided a definition of mountain lakes as being "smaller-sized natural lakes, which are located at least 1000 meters above sea level."

- Section 2 referred to CES. We selected CES that are associated with mountain lakes based on the latest version of the Common International Classification of Ecosystem Services (CICES; Haines-Young and Potschin 2018) because the CICES is widely used in mapping efforts and policies in Europe. It offers a high level of detail and it is partly based on previous classification systems used in the Millennium Ecosystem Assessment (MEA), the Economics of Ecosystems and Biodiversity (TEEB), and different national ecosystem assessments (Burkhard and Maes 2017). We asked the respondents in a closed question to indicate how accurate the provided statements related to CES (Table 1) were on a four-point rating scale ("does not apply at all," "does not really apply," "somewhat applies," "definitely applies") with an additional option for "I don't know."

- In section 3, we asked the respondents about their perceptions of experiences. Based on literature describing different facets of subjective well-being (Russell et al. 2013, Bryce et al. 2016), we selected different types of experiences (Table 2) that can be associated with a visit to mountain lakes. Perceptions of experiences were collected using closed questions, asking the respondents to indicate how accurate the provided statements (Table 2) were on a five-point rating scale from 1 ("does not apply at all") to 5 ("definitely applies").

- In section 4, we included an open-ended question linked to the pressures on experiences related to a visit to a mountain 
Table 1. Selection of cultural ecosystem services (CES) based on the Common International Classification of Ecosystem Services (CICES; Haines-Young and Potschin 2018) and description used in the questionnaire.

\begin{tabular}{lll}
\hline \hline CES & CICES & Description [Mountain lakes are...] \\
\hline Outdoor recreation & 3.1 .1 .1 & suitable for leisure activities \\
Scientific research & 3.1 .2 .1 & suitable for research purposes \\
Education & 3.1 .2 .2 & suitable to transfer knowledge about nature \\
Sense of place & 3.1 .2 .3 & places that convey a sense of home, of belonging \\
Aesthetic value & 3.1 .2 .4 & places of great aesthetic value \\
Symbolic value & 3.2 .1 .1 & places with symbolic power \\
Spiritual value & 3.2 .1 .2 & places of spirituality \\
Representation & 3.2 .1 .3 & suitable for advertising, e.g., of products \\
Entertainment & 3.2 .1 .3 & suitable for commercial purposes, e.g., film location \\
Existence value & 3.2 .2 .1 & essential elements of alpine landscapes \\
Bequest value & 3.2 .2 .2 & worth preserving in their natural state \\
& & $!$ \\
\hline
\end{tabular}

lake ("You are visiting a mountain lake. In your opinion, what could diminish your experience of this visit and discourage you from extending your stay? Please, briefly describe this in a few words."). Such free listings are commonly used to elicit cognitive data, which can also be useful to generate in-depth insights on CES (Bieling et al. 2014, Wartmann and Purves 2018).

- In section 5 at the end of the questionnaire, we asked the participants to provide information on gender, age, their relation to the Alps, frequency of visits in nature, and lake affinity (see also Fig. A2.1). The answers were not required, and respondents could complete the questionnaire without filling out the responses. The information from this section was used to compare perceptions across socio-cultural groups (Table 3 ).

A complete draft of the questionnaire was sent to 17 people, selected to represent the target population, that is, people of different gender, age, educational level, profession, and living in and outside the European Alps. In this pre-test, participants filled out the questionnaire and provided feedback on the presentation, clarity, and completeness of the questions and response options. After evaluating and incorporating suggested changes, the final questionnaire was translated into the three languages: English, German, and Italian.

\section{Data collection}

Data were collected via an online survey focusing on respondents living in or visiting the European Alps. The European Alps are the highest mountain range in Europe, extending over about $192,000 \mathrm{~km}^{2}$ across different cultures and societies. They include about 6000 small natural lakes (between $0.005 \mathrm{~km}^{2}$ and $1 \mathrm{~km}^{2}$ ) that are located above $800 \mathrm{~m}$ a.s.1. (Schirpke et al. 2021a). Being also one of the most important European touristic destinations with more than 100 million visitors each year (Batista e Silva et al. 2018), the greater Alpine region is suitable for analyzing perceptions related to CES of mountain lakes and to examine the socio-cultural influence on values.

The questionnaire was made available between July and December 2020. We targeted people that directly benefit from
CES of mountain lakes, for example, during hiking excursions, such as members of Alpine clubs or people with a professional interest in mountain lakes such as members of associations of biologists, limnologists, etc. To reach many potential respondents living or working in the European Alps and surroundings, we asked various organizations to distribute the links to the questionnaires via their newsletters and social media channels (e. g., Facebook). Our request was supported by the Alpine clubs of different countries (Austria, Germany, and Italy), different associations of biologists and limnologists in Austria and Northern Italy, and the International Commission for the Protection of the Alps (CIPRA), among others. Moreover, we sent invitations via email to research partners and colleagues located in and around the European Alps with the request to forward the links also to their relatives, friends, and colleagues. The responses of all completed questionnaires were registered in a database. Before filling out the questionnaire, the participants were informed that the study was carried out in accordance with national and institutional legal and ethical requirements, i.e., that participation was anonymous and on a voluntary basis (see Appendix 1). All participants also confirmed their voluntary participation. To secure privacy, all data were collected via a web survey with no collection of identifiers/codes and therefore analyzed anonymously.

\section{Data analysis}

We analyzed the responses using a combination of qualitative and quantitative methods. To quantify the values of CES and experiences, we assigned numeric values to each answer of a respective question $(0=$ does not apply at all/don't know, $1=$ does not really apply, $2=$ somewhat applies, $3=$ definitely applies). We then calculated the mean value for each CES and type of experience from these values. For a comparison of values across different socio-cultural groups, we categorized the respondents into groups of similar sample size based on different sociocultural variables (Table 3). Because some respondents did not provide information of all or some socio-cultural variables, sample sizes may differ from the total sample. Groups with a very small sample size were excluded, e.g., English-speaking respondents $(n=22)$. We calculated the mean values of CES, experiences, and pressures for each group using cross-tabulation 
Table 2. Experiences and description used in the questionnaire. Categories were selected and adapted from Russell et al. (2013) and Bryce et al. (2016).

\begin{tabular}{lll}
\hline \hline Category of well-being & Experience & Description \\
\hline Experiences & Connection to nature & In a place like this, I feel in touch with nature \\
& Freedom & Visiting a place like this gives me a sense of freedom \\
& Peace & A place like this instills inner peace within me \\
Capabilities & Life lessons & Visiting a place like this leaves me with the feeling that I have learned \\
& Inspiration & Something from nature \\
& Memories & In a place like this, I find inspiration \\
Identities & Sense of belonging & A place like this makes me feel at home \\
& Relaxation & Having visited a place like this, I feel more relaxed \\
Mental restoration & Excitement & In a place like this, I feel excited \\
& Health & Having spent time at a place like this, I feel healthier \\
Physical benefits & Refreshment & This is a place to refresh and cool down on particularly hot days \\
&
\end{tabular}

and Chi-Square tests to assess the significance of the differences between groups.

We assessed the relations between individual types of CES and experiences as well as between CES and experiences using correlation analysis to quantitatively evaluate positive and negative relationships (Cord et al. 2017). For each pair, we calculated bivariate correlations (Pearson's r coefficient) in SPSS Statistics (IBM SPSS 26), indicating the strength and direction of the relationship. All significant correlations were plotted as correlograms using the package corrplot version 3.3.3 for R ( R Core Development Team 2019).

Pressures were identified from the open-ended question adopting a qualitative analysis of free lists (Bieling et al. 2014, Wartmann and Purves 2018). All German and Italian responses were translated into English merging conceptually and semantically similar terms (e.g., too many people/crowds of people, rubbish/ garbage), which resulted in 90 different terms. Based on the frequencies of these terms, we identified six broader categories of pressures (crowdedness, noisiness, garbage/pollution, touristic exploitation, bad weather, and anthropization). We then assigned all responses to one or more categories, which were coded into presence/absence. Mentions that did not fit into one of the categories were summarized in a separate category (other). The pressures were also examined for differences between sociocultural groups using a Chi-Square test.

To identify the differences in the influence of pressures on experiences and consequently on CES, we coded all variables into presence/absence, assigning 1 to "definitely applies" and 0 to all other response options of experiences. We then created correspondence tables to depict the relations between pressures and experiences in a Sankey plot using SankeyMATIC (http:// sankeymatic.com/build/). Similarly, the correlations between experiences and CES were assessed using only significant correlations between experiences and CES $(\mathrm{p} \leq 0.001)$.

\section{RESULTS}

Characteristics of respondents

In total, we obtained 526 valid responses, with a higher share of female respondents $(61 \%)$, more German-speaking people $(56 \%)$, and almost 50\% were younger than 45 years (Fig. A2.1). In terms of their relation to the European Alps, the largest group were respondents visiting the Alps for touristic purposes (44\%), followed by residents who were also born in the Alps (38\%). A high share of the respondents had frequent contact with nature spending time in nature at least several times a week (64\%). More than half of all respondents $(54 \%)$ also indicated a high lake affinity because they visited mountain lakes at least four times a year.

\section{CES relating to mountain lakes}

Respondents attributed the highest value to bequest values, followed by symbolic values, aesthetic values, education, spiritual values, and existence values, whereas entertainment and representation obtained the lowest values of all CES (Fig. 1). Across the socio-cultural groups, high statistically significant differences $(p \leq 0.001)$ in the valuation of individual CES mainly occurred in relation to cultural background (Table A2.1). Accordingly, German-speaking respondents valued symbolic and spiritual values higher than Italian-speaking respondents, who in turn perceived scientific research, existence value, education, and sense of place as more important. Although almost all sociocultural groups agreed on bequest value as being the most important CES, some differences in the rankings of CES occurred as well although they were not always significant (Table A2.1). For example, female respondents valued symbolic values slightly higher than aesthetic values, whereas male respondents assigned higher values to existence values than to symbolic values.

CES were partly correlated to each other (Fig. 2). The highest synergies occurred between symbolic and spiritual values. Bequest values correlated with many other CES, mainly with existence, spiritual, symbolic, and aesthetic values, while existence values were more related to scientific research, education, aesthetic value, and sense of place. The only negative correlation was found between scientific research and spiritual value.

\section{Experiences relating to mountain lakes}

In terms of experiences, the highest values occurred for connection to nature, relaxation, and freedom, followed by peace and memories (Fig. 3). The greatest differences between sociocultural groups occurred for gender (Table A2.2): female 
Table 3. Socio-cultural groups used to identify their influence on values of cultural ecosystem services (CES) and experiences. Groups may differ in sample size from the total sample $(\mathrm{n}=256)$, as not all respondents provided information for each variable. Further groups with a very small sample size were excluded.

\begin{tabular}{llc}
\hline \hline Socio-cultural variables & & Sample size \\
\hline Gender & Female & 320 \\
& Male & 201 \\
Age & 16-39 years & 253 \\
& 40+ years & 256 \\
Cultural background & German-speaking & 294 \\
& Italian-speaking & 210 \\
Relation to Alps & Low (visits the Alps primarily as a tourist) & 229 \\
& Strong (lives and grew up in the Alps) & 199 \\
Frequency of visits in & Low (spending time in nature less than several times a month) & 187 \\
nature & & 335 \\
& High (spending time in nature at least several times a week) & 255 \\
Lake affinity & Low (< three visits to lakes a year) & 268 \\
& High (> four visits to lakes a year) & \\
\hline
\end{tabular}

respondents generally valued experiences higher than male respondents, in particular, connection to nature, relaxation, peace, memories, health, inspiration, and excitement. Sense of belonging was more important for respondents with high lake affinity, residents, as well as respondents with frequent visits in nature.

Fig. 1. Values of cultural ecosystem services (CES) of mountain lakes with $95 \%$ confidence intervals. Values with nonoverlapping confidence intervals are significantly different from each other. Same color bars indicate groups of CES for which the values do not differ significantly from each other. Letters indicate statistically significant differences in values between socio-cultural groups: (a) gender, (b) age, (c) cultural background, (d) relation to Alps, (e) frequency of visits in nature, and (f) lake affinity.

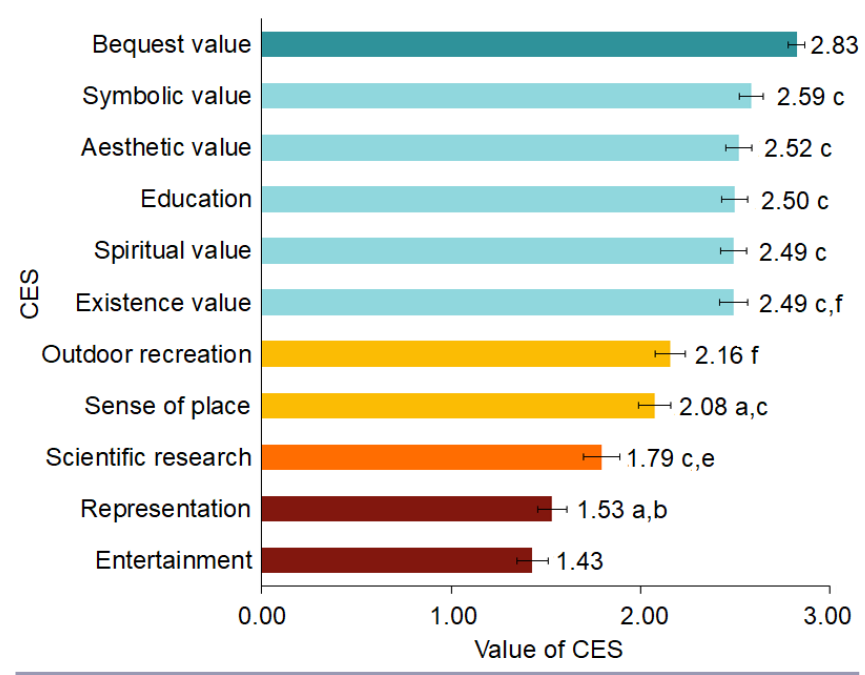

Fig. 2. Bivariate correlations (Pearson's r coefficient) across cultural ecosystem services (CES) with a significance level of $p$ $\leq 0.01$. Strength shown through Pearson's $r$ coefficient, represented by the size of the circles. Circles with different shades of blue indicate positive correlations and the circles in yellow shades represent negative correlations.

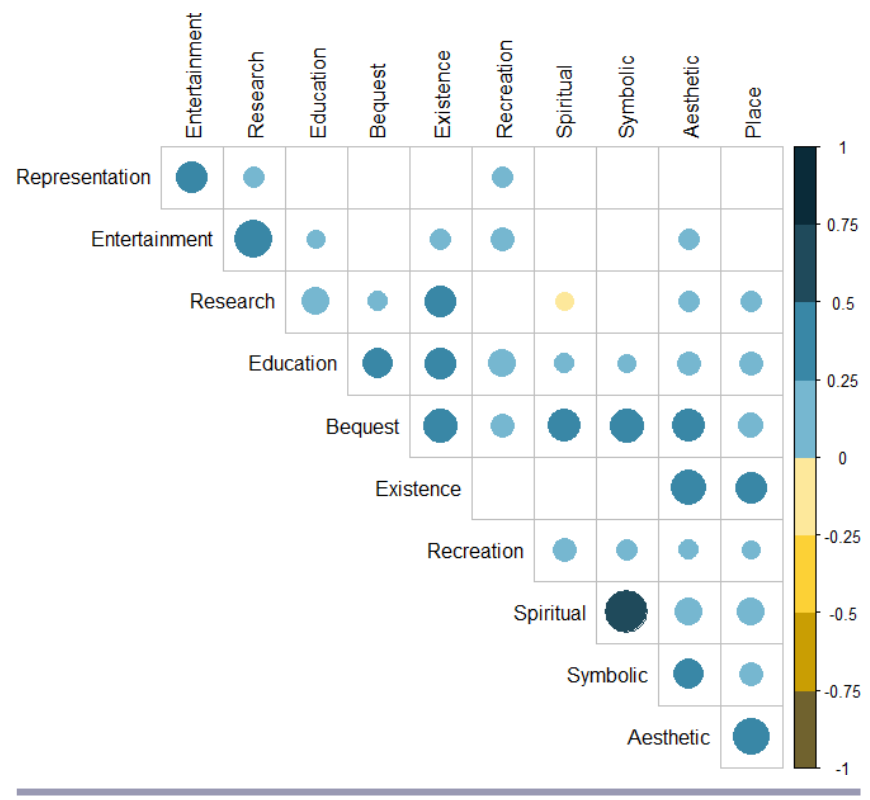

Synergies occurred between most experiences (Fig. 4). The highest synergies were found between connection to nature and peace. Freedom and excitement were related to all other experiences with the exception of life lessons, whereas the weakest synergies generally occurred for refreshment and life lessons. Some positive and negative correlations were also found between CES and experiences (Fig. A2.2). Experiences were mainly related to 
aesthetic value, existence value, and sense of place, specifically, inspiration, sense of belonging, health, life lessons, freedom, and connection to nature. Weak negative correlations were found between sense of belonging and outdoor recreation as well as between memories and scientific research. Although refreshment was only related to representation, none of the experiences correlated with entertainment.

Fig. 3. Values of experiences of mountain lakes with $95 \%$ confidence intervals. Values with non-overlapping confidence intervals are significantly different from each other. Same color bars indicate groups of cultural ecosystem services (CES) for which the values do not differ significantly from each other. Letters indicate statistically significant differences in value between socio-cultural groups: (a) gender, (b) age, (c) cultural background, (d) relation to Alps, (e) frequency of visits in nature, and (f) lake affinity.

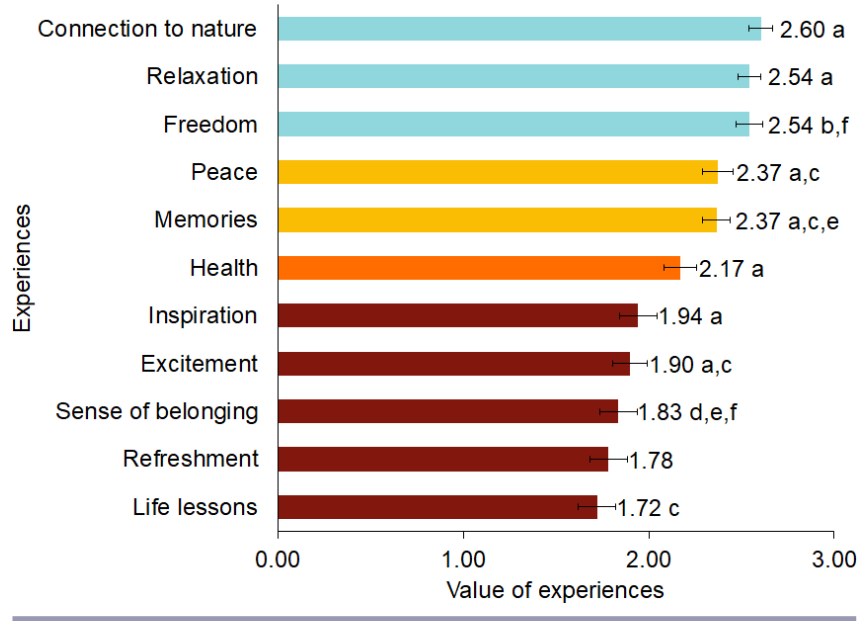

\section{Pressures on experiences and CES}

Based on the responses to the open-ended question, we identified several pressures that would diminish the experience or prevent extending the visit to mountain lakes. Most often respondents mentioned crowdedness $(70.0 \%)$, followed by noisiness $(27.2 \%)$, garbage/pollution $(21.3 \%)$, touristic exploitation (18.6\%), bad weather $(12.0 \%)$, anthropization $(11.8 \%)$, and other aspects (4.6\%; e.g., disturbance by animals or difficult access). Some significant differences occurred between socio-cultural groups (Table A2.3). A higher share of German-speaking respondents mentioned noisiness, garbage, and touristic exploitation compared to Italian-speaking people. Although noisiness was indicated more often by female respondents, garbage/pollution was stated more often by younger people.

In general, the indicated pressures mostly affected connection to nature, freedom, relaxation, peace, and memories, while having lower impacts on excitement and life lessons (Fig. 5). Garbage/ pollution and anthropization seemed to affect all experiences similarly, whereas the other pressures had some statistically significant differences. Crowdedness had the greatest impact on freedom and sense of belonging. Unlike touristic exploitation, noisiness had the greatest negative effect on inspiration and the least effects on the sense of belonging and refreshment. Bad weather had the highest influence on life lessons, while the other mentioned pressures were most important for refreshment. These negative impacts on experiences also affected CES at different levels (Fig. 5). Relaxation $(13.9 \%)$, peace $(13.0 \%)$, freedom $(11.9 \%)$, and inspiration (11.5\%) had the highest impacts on CES, mostly affecting aesthetic value $(22.6 \%)$, followed by sense of place $(20.5 \%)$, existence value $(18.2 \%)$, and symbolic value $(15.2 \%)$.

Fig. 4. Bivariate correlations (Pearson's $r$ coefficient) across experiences with a significance level of $p \leq 0.01$. Strength shown through Pearson's r coefficient, represented by the size of the circles. Circles with different shades of blue indicate positive correlations and the circles in yellow shades represent negative correlations.

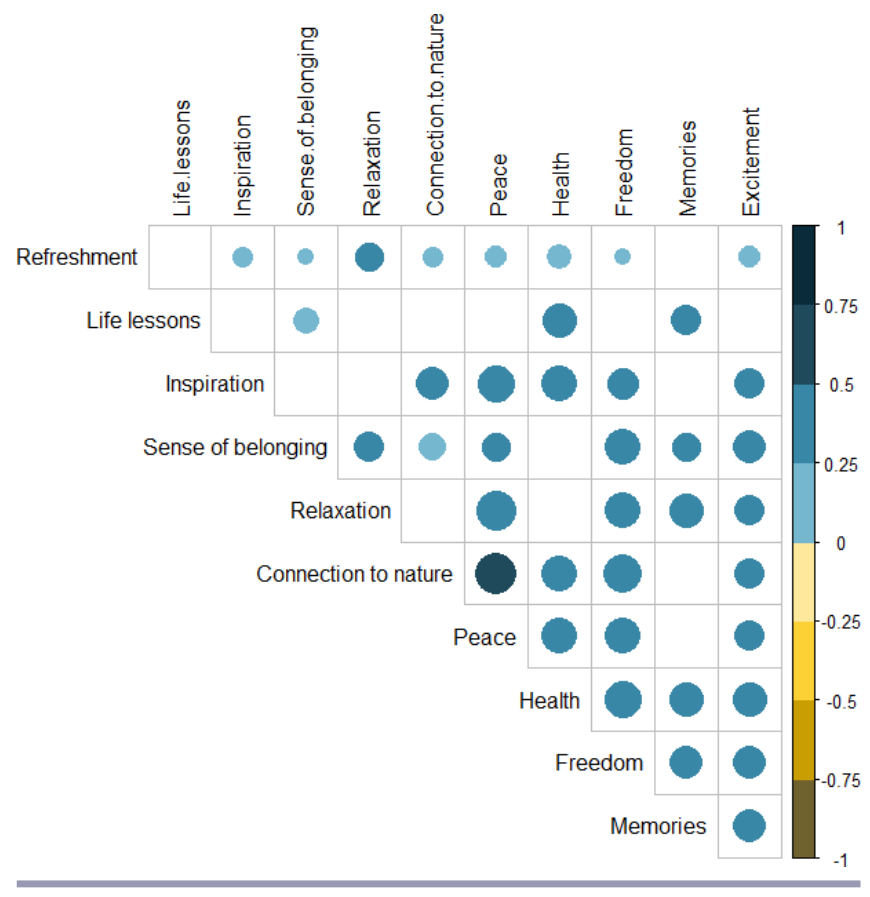

\section{DISCUSSION}

\section{CES and experiences relating to mountain lakes}

In many studies examining the perceptions of various CES across different landscapes, outdoor recreation was found to be one of the most valued CES (Bieling et al. 2014, Rall et al. 2017, Ko and Son 2018). Accordingly, studies emphasized the importance of large and low elevation lakes for aquatic activities such as swimming or boating (Allan et al. 2015, Sterner et al. 2020, Pröbstl-Haider et al. 2021, Schirpke et al. 2021a). In contrast, we found that mountain lakes are most appreciated for intrinsic values, as has been reported in previous studies, which found that aesthetic or spiritual values were deemed more important than recreation (Ament et al. 2017, Riechers et al. 2018). In our case, the preference for symbolic, aesthetic, spiritual, and existence values can be explained by harsh climatic conditions at high elevations and the remoteness of the lakes (Schirpke et al. 2021a). Consequently, water-based activities are less important in mountain lakes than other recreational activities that are carried out in the surrounding landscape, such as hiking or biking that 
Fig. 5. Impacts of pressures (left) on experiences (center) and related cultural ecosystem services (CES; right). Only significant relations between experiences and CES were included (see Fig. A1.2). The width of the lines indicates the magnitude of influence, and the colors show individual pressures, experiences, and CES.

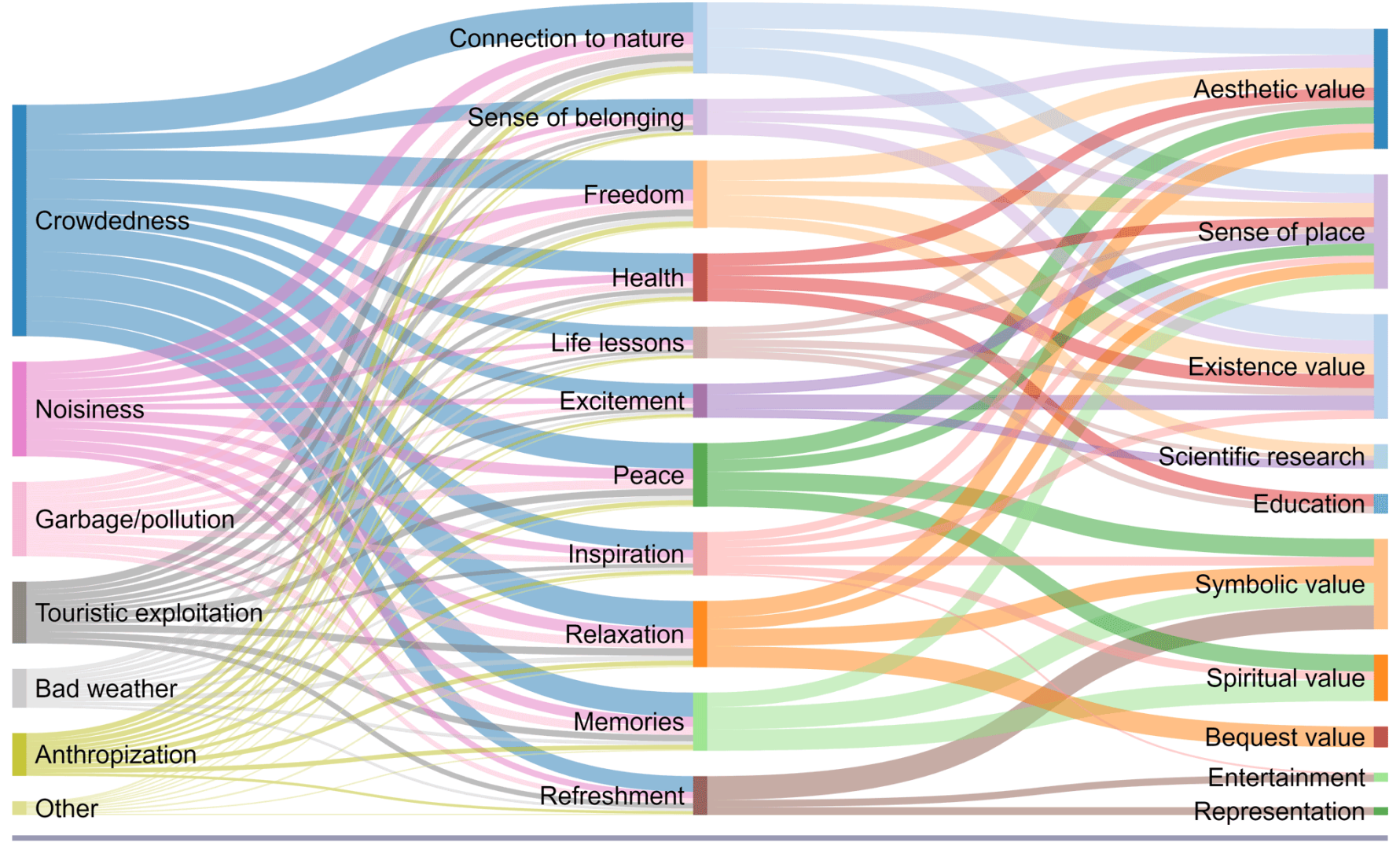

do not require direct contact with the lake (Pröbstl-Haider et al. 2021, Schirpke et al. 2021b). This is also reflected in the most valued experiences, which are related to mental and restorative experiences such as connection to nature, relaxation, and freedom, while respondents deemed physical benefits provided by mountain lakes as less relevant.

By analyzing the correlations between CES and experiences, our results indicate high positive correlations between three CES (aesthetic value, existence value, and sense of place) with most of the experiences (Fig. A2.2). This high level of interrelation and overlap has also been acknowledged in previous studies in a similar way (Bieling et al. 2014, Hausmann et al. 2016, Wartmann and Purves 2018). The two negative correlations that emerged suggest that there are distinct user groups with specific preferences regarding some CES (outdoor recreation vs. sense of belonging and scientific research vs memory), which probably do not overlap. Other studies mention such similar competing interests, for example, in relation to recreational activities or biodiversity conservation goals (Ament et al. 2017, Roux et al. 2020). Sense of belonging was highest valued by people with high lake affinity regardless of being resident or tourist, whereas for outdoor recreation the opposite was true. Therefore, diverging interests seem to be related to specific values that are not limited to specific socio-cultural groups but rather to their value orientations (Kaltenborn and Bjerke 2002). This also allows the binary distinction between residents and tourists to be overcome and for intermediate categories of beneficiaries to be identified, e.g., tourists with a high lake affinity with similar perceptions compared to specific groups of residents. This understanding can be important for local institutions to promote a certain type of tourism through a more conscientious infrastructure development and accounting for social-ecological impacts over time (Haraldsson and Ólafsdóttir 2018).

\section{Socio-cultural differences}

Although almost all socio-cultural groups agreed that mountain lakes are "worth preserving in their natural state," most differences in values of other CES emerged between groups with different cultural backgrounds. These findings are supported by other studies pointing out the importance of accounting for sociocultural differences (Soliva et al. 2010, Zoderer et al. 2016a, b, Quintas-Soriano et al. 2018, Dou et al. 2020). For example, many studies found differences between male and female respondents, suggesting that women more often indicate immaterial values than men (Plieninger et al. 2013, Nowak-Olejnik et al. 2020). In concordance with these findings, women attributed higher values to sense of place in our study, while men scored higher representation. Such differences were even more pronounced in the valuation of the experiences, of which 7 out of 11 received significantly higher values from women, in particular excitement, inspiration, and peace, while refreshment and life lessons were evaluated most similarly. 
The differences across socio-cultural groups reflect that different uses and experiences are appreciated by different types of beneficiaries (Van Berkel and Verburg 2014, Scolozzi et al. 2015, Ament et al. 2017, Small et al. 2017, Schirpke et al. 2018). Regarding mountain lakes, our results suggest two orientations between the groups: (1) people who are more practice-oriented (doing, enjoying, teaching, and learning something), and (2) people with a more reflexive orientation (contemplating, meditation moments, regardless of any particular activities). By integrating further information on the preferred activities and pressures, this information can be used as a basis for further analysis to anticipate potential conflicts between groups with different preferences (Confer et al. 2005, Schirpke et al. 2020).

\section{Pressures on CES and experiences}

Our results clearly indicate that crowdedness is the most frequently mentioned pressure on the quality of nature-based experiences, agreeing with previous empirical and recreational studies (Moyle and Croy 2007, Arnberger and Mann 2008, Zehrer and Raich 2016, Roux et al. 2020). Perceived crowdedness is considered to be the subjective negative evaluation of density levels in a specific location, emerging when the actual experience diverges from the expectations (Oliver 1980). These expectations can be influenced by gender, age, frequency of visit, and specific situations (Zehrer and Raich 2016). Confer et al. (2005) found that garbage, noise, and congestion increase negative associations with recreational activities, resulting in less tolerance toward other users. Similarly, our results suggest that the behavior of other visitors is decisive in interfering with experiences, as many respondents also specified noisiness (e.g., loud music, screaming people) or garbage left around the lake. The pressures may also be linked to different types of activities, which can provoke conflicts between different user groups (Scolozzi et al. 2015, Schirpke et al. 2020); in the case of mountain lakes, these may be people visiting lakes alone or with their partner to enjoy the quietness versus people having a barbecue with friends. In addition, these pressures also affect highly valued CES such as aesthetic value, sense of place, existence value, and symbolic value. Here, management measures could start with specific interventions for raising awareness on abandoned garbage or exhibiting respective behavior toward nature and other people. As in Lapointe et al. (2020), we found some significant differences between socio-cultural groups in pressures, indicating that Italian-speaking respondents are more tolerant toward noisiness, garbage, and touristic exploitation.

\section{Management implications}

Our findings emphasize the importance of mountain lakes in providing CES and experiences, but also call for more attention from decision makers and managers as stressed by the indicated pressures, in particular crowdedness. Previous research on crowdedness mostly concerned built environments (e.g., urban areas and urban parks) or specific contexts, such as ski areas, national parks, or forests (Moyle and Croy 2007, Arnberger and Mann 2008, Kainzinger et al. 2015, Roux et al. 2020). Open landscapes, however, have received less attention in studies addressing the interrelationships between crowdedness and the benefits of CES. Such research is particularly important in the light of global megatrends because it is expected that relatively remote and natural places will experience increasing pressures in the coming decades because of a constantly growing demand for nature-based experiences (Buckley et al. 2015), despite and possibly also due to economic and health crises (Gössling et al. 2021, Wen et al. 2021). Hence, efforts should be made to identify carrying capacities to support visitor management plans, which should also account for the impacts of recreational activities on lake ecosystems (Dokulil 2014, Senetra et al. 2020). These could be integrated with voluntary codes of conduct for hikers/tourists for attentive and considerate behaviors toward other visitors.

Beyond the regional and national borders, the European Alps can be considered as a large natural area in the center of a vast urbanized area, providing high levels of CES and being exposed to similar pressures and trends (Schirpke et al. 2019, Egarter Vigl et al. 2021). Therefore, increasing pressures from socioeconomic and climatic changes can also be expected on mountain lakes in the future, requiring the attention of decision makers. Mountain lakes are particularly vulnerable to increasing use, including water abstraction, livestock farming, tourism, and hydropower generation, and such pressures may severely affect the lake ecosystem and related CES (Dokulil 2014, Van Colen et al. 2018, Schmeller et al. 2018, Brunner et al. 2019, Moser et al. 2019). In addition, these pressures may escalate the competing interests of different users (Schirpke et al. 2020). A careful evaluation of potential environmental impacts is therefore necessary before the construction of new infrastructures, the increase of farming activities, or the promotion of lakes as a tourist destination. By understanding and acknowledging societal values as well as individual well-being benefits, as reported in this study, decision makers may be able to better balance potential impacts and conflicts. For example, considering the high perception of intrinsic values, tourism management and nature conservation may pool forces to maintain the high environmental quality of lakes, while offering opportunities to visitors to engage with nature to encourage pro-environmental behaviors (Mackay and Schmitt 2019).

\section{Limitations and future directions}

Our study is limited by several factors. One is related to our sample, because we aimed to collect perceptions of people that directly benefit from CES of mountain lakes, also asking mountaineering associations to inform their members about the survey. We can therefore assume that the sample of respondents represents mostly people with a high interest in hiking and an elevated level of nature awareness because the mountaineering associations are very engaged in protecting the environment and supporting a sustainable development of the mountain regions. Accordingly, only $5 \%$ of the respondents never visit mountain lakes, meaning that our results do not sufficiently reflect the preferences of other types of visitors, e.g., mountain bikers and leisure tourists (Scolozzi et al. 2015) or anglers and kayakers (Confer et al. 2005). Moreover, our results mostly depict the perceptions of German-speaking and Italian-speaking people, but it would also be interesting to include people with other cultural backgrounds, which seems to be a key factor for differences in perceptions of CES. Future studies should also account for psycho-cultural aspects to improve the understanding of human behavior and human-nature interactions, which can improve management issues and improve the characterization of the respondents (Kumar and Kumar 2008).

Another issue is related to the choice of using an online-survey because of Covid-19 restrictions. This is a disadvantage when 
including open-ended questions because we could not ask participants to specify their answers as during interviews in situ (e.g., Bieling et al. 2014, Wartmann and Purves 2018). For example, many people indicated "too many people" as a pressure, but there was no indication of how many people and whether these people posed a disturbance simply because of their presence or because of a specific behavior, e.g., screaming or leaving garbage. Nevertheless, the broad categorization of the mentioned pressures matches those used in other studies (Confer et al. 2005, Roux et al. 2020), and the results are a useful starting point for further studies. Further research could investigate the "style of enjoyment" for each type of visitor to identify and possibly anticipate important issues for destination management. This could include a potential impact profile (e.g., high or low tendency to litter, high or low potential for noisiness) and sensitivity to crowdedness (e.g., ranges in the number of other users on the same site that make people feel like it is crowded). These would require research approaches similar to those used in market studies, in which the variables can be controlled; this is feasible for specific variables but difficult to perform for open landscape features such as mountain lakes.

Concerning destination management, previous examples include the models of wildlife tourism established in several British destinations (Curtin 2013). However, in the macro-region of the European Alps, an area with a high complexity of institutions and diversity of administration forms, this would require longterm visions and an anticipatory governance approach (Jurgilevich 2021) to be shared between destination marketers, local administrations, conservation NGOs, and private sector operators.

\section{CONCLUSIONS}

This study addressed several challenges related to the assessment of CES and focused on small mountain lakes, which are different from many other ecosystems studied in terms of recognized appreciation and values. First, by distinguishing between CES and experiences, this study emphasizes synergies between a variety of values associated with small mountain lakes. This provides a basis for better consideration of CES in nature-based tourism and conservation management because it encourages decision makers and landscape managers to evaluate how interventions that affect the lake characteristics can change experiences. Second, mountain lakes are relatively more sensitive to global megatrends and local pressures (e.g., nature-based tourism and outdoor recreation, climate change) than large lakes, and therefore require the attention of decision makers. This study provides novel insights into the variety of values people associate with mountain lakes and recognizes the potential pressures on related experiences. Finally, our results relating to the socio-cultural groups suggest that there are different user groups with distinct preferences and value orientations, with lake enjoyment varying from more active and recreational to more contemplative practices. Unlike previous studies on other natural areas, these groups are not binarily divided between residents and visitors; gender, age, cultural background, lake affinity, and frequency of visits in nature indicate finer differences in perceived values between the groups. This understanding can be important for institutions to promote sustainable tourism through a more aware infrastructure development and accounting for social-ecological impacts over time.
Responses to this article can be read online at: https://www.ecologyandsociety.org/issues/responses. $\mathrm{php} / 12987$

\section{Acknowledgments:}

This research was carried out within the project CLAIMES (CLimate response of AlpIne lakes: resistance variability and Management consequences for Ecosystem Services) under the Earth System Sciences research programme, which is an initiative of the Austrian Academy of Sciences financed by the Austrian Federal Ministry of Education, Science and Research. We acknowledge the contribution by Alexander Kiessling in developing and distributing the questionnaire. We also thank all respondents for their participation and valuable answers. The authors thank the Department of Innovation, Research, University and Museums of the Autonomous Province of Bozen/Bolzano for covering the Open Access publication costs.

\section{Data Availability:}

The data that support the findings of this study are summarized in Appendix 2. Further data are available on request from the corresponding author, US. The research was carried out in accordance with national and institutional legal and ethical requirements. Participation was voluntary, all data were collected anonymously, and respondents were asked to provide their informed consent.

\section{LITERATURE CITED}

Allan, J. D., S. D. P. Smith, P. B. McIntyre, C. A. Joseph, C. E. Dickinson, A. L. Marino, R. G. Biel, J. C. Olson, P. J. Doran, E. S. Rutherford, J. E. Adkins, and A. O. Adeyemo. 2015. Using cultural ecosystem services to inform restoration priorities in the Laurentian Great Lakes. Frontiers in Ecology and the Environment 13(8):418-424. https://doi.org/10.1890/140328

Ament, J. M., C. A. Moore, M. Herbst, and G. S. Cumming. 2017. Cultural ecosystem services in protected areas: understanding bundles, trade-offs, and synergies. Conservation Letters 10 (4):440-450. https://doi.org/10.1111/conl.12283

Angradi, T. R., J. J. Launspach, D. W. Bolgrien, B. J. Bellinger, M. A. Starry, J. C. Hoffman, A. S. Trebitz, M. E. Sierszen, and T. P. Hollenhorst. 2016. Mapping ecosystem service indicators in a Great Lakes estuarine area of concern. Journal of Great Lakes Research 42(3):717-727. https://doi.org/10.1016/j.jglr.2016.03.012

Angradi, T. R., J. J. Launspach, and R. Debbout. 2018. Determining preferences for ecosystem benefits in Great Lakes areas of concern from photographs posted to social media. Journal of Great Lakes Research 44(2):340-351. https://doi. org/10.1016/j.jglr.2017.12.007

Arnberger, A., and C. Mann. 2008. Crowding in European forests: a review of recent research and implications for forest management and policy. Forestry: An International Journal of 
Forest Research 81(4):559-571. https://doi.org/10.1093/forestry/ cpn034

Batista e Silva, F., M. A. Marín Herrera, K. Rosina, R. Ribeiro Barranco, S. Freire, and M. Schiavina. 2018. Analysing spatiotemporal patterns of tourism in Europe at high-resolution with conventional and big data sources. Tourism Management 68:101-115. https://doi.org/10.1016/j.tourman.2018.02.020

Bell, S. L., R. Foley, F. Houghton, A. Maddrell, and A. M. Williams. 2018. From therapeutic landscapes to healthy spaces, places and practices: a scoping review. Social Science and Medicine 196:123-130. https://doi.org/10.1016/j.socscimed.2017.11.035

Bieling, C., T. Plieninger, H. Pirker, and C. R. Vogl. 2014. Linkages between landscapes and human well-being: an empirical exploration with short interviews. Ecological Economics 105:19-30. https://doi.org/10.1016/j.ecolecon.2014.05.013

Brunner, M. I., A. Björnsen Gurung, M. Zappa, H. Zekollari, D. Farinotti, and M. Stähli. 2019. Present and future water scarcity in Switzerland: potential for alleviation through reservoirs and lakes. Science of The Total Environment 666:1033-1047. https:// doi.org/10.1016/j.scitotenv.2019.02.169

Bryce, R., K. N. Irvine, A. Church, R. Fish, S. Ranger, and J. O. Kenter. 2016. Subjective well-being indicators for large-scale assessment of cultural ecosystem services. Ecosystem Services 21:258-269. https://doi.org/10.1016/j.ecoser.2016.07.015

Buckley, R., U. Gretzel, D. Scott, D. Weaver, and S. Becken. 2015. Tourism megatrends. Tourism Recreation Research 40(1):59-70. https://doi.org/10.1080/02508281.2015.1005942

Burkhard, B., and J. Maes, editors. 2017. Mapping ecosystem services. Pensoft Publishers, Sofia, Bulgaria. https://doi. org/10.3897/ab.e12837

Chan, K. M. A., T. Satterfield, and J. Goldstein. 2012. Rethinking ecosystem services to better address and navigate cultural values. Ecological Economics 74:8-18. https://doi.org/10.1016/j. ecolecon.2011.11.011

Cheng, X., S. Van Damme, L. Li, and P. Uyttenhove. 2019. Evaluation of cultural ecosystem services: a review of methods. Ecosystem Services 37:100925. https://doi.org/10.1016/j.ecoser.2019.100925

Confer, J. J., B. Thapa, and J. L. Mendelsohn. 2005. Exploring a typology of recreation conflict in outdoor environments. World Leisure Journal 47(1):12-23. https://doi.org/10.1080/04419057.2$\underline{005.9674382}$

Cord, A. F., B. Bartkowski, M. Beckmann, A. Dittrich, K. Hermans-Neumann, A. Kaim, N. Lienhoop, K. Locher-Krause, J. Priess, C. Schröter-Schlaack, N. Schwarz, R. Seppelt, M. Strauch, T. Václavík, and M. Volk. 2017. Towards systematic analyses of ecosystem service trade-offs and synergies: main concepts, methods and the road ahead. Ecosystem Services 28:264-272. https://doi.org/10.1016/j.ecoser.2017.07.012

Curtin, S. 2013. Lessons from Scotland: British wildlife tourism demand, product development and destination management. Journal of Destination Marketing and Management 2 (3):196-211. https://doi.org/10.1016/j.jdmm.2013.09.002
Daniel, T. C., A. Muhar, A. Arnberger, O. Aznar, J. W. Boyd, K. M. A. Chan, R. Costanza, T. Elmqvist, C. G. Flint, P. H. Gobster, A. Grêt-Regamey, R. Lave, S. Muhar, M. Penker, R. G. Ribe, T. Schauppenlehner, T. Sikor, I. Soloviy, M. Spierenburg, K. Taczanowska, J. Tam, and A. Von Der Dunk. 2012. Contributions of cultural services to the ecosystem services agenda. Proceedings of the National Academy of Sciences of the United States of America 109(23):8812-8819. https://doi.org/10.1073/pnas.1114773109

Dokulil, M. T. 2014. Environmental impacts of tourism on lakes. Pages 81-88 in A. A. Ansari and S. S. Gill, editors. Eutrophication: causes, consequences and control: Volume 2. Springer, Dordrecht, The Netherlands. https://doi.org/10.1007/978-94-007-7814-6 7

Dou, Y., X. Yu, M. Bakker, R. De Groot, G. J. Carsjens, H. Duan, and C. Huang. 2020. Analysis of the relationship between crosscultural perceptions of landscapes and cultural ecosystem services in Genheyuan region, Northeast China. Ecosystem Services 43:101112. https://doi.org/10.1016/j.ecoser.2020.101112

Egarter Vigl, L., T. Marsoner, U. Schirpke, S. Tscholl, S. Candiago, and D. Depellegrin. 2021. A multi-pressure analysis of ecosystem services for conservation planning in the Alps. Ecosystem Services 47:101230. https://doi.org/10.1016/j.ecoser.2020.101230

Fish, R., A. Church, and M. Winter. 2016. Conceptualising cultural ecosystem services: a novel framework for research and critical engagement. Ecosystem Services 21:208-217. https://doi. org/10.1016/j.ecoser.2016.09.002

Fu, B., P. Xu, Y. Wang, K. Yan, and S. Chaudhary. 2018. Assessment of the ecosystem services provided by ponds in hilly areas. Science of the Total Environment 642:979-987. https://doi. org/10.1016/j.scitotenv.2018.06.138

Gössling, S., D. Scott, and C. M. Hall. 2021. Pandemics, tourism and global change: a rapid assessment of COVID-19. Journal of Sustainable Tourism 29(1):1-20. https://doi.org/10.1080/096695$\underline{82.2020 .1758708}$

Haines-Young, R., and M. Potschin. 2018. Common international classification of ecosystem services (CICES) V5. 1. Guidance on the Application of the Revised Structure. Fabis Consulting, Nottingham, UK.

Haraldsson, H. V., and R. Ólafsdóttir. 2018. Evolution of tourism in natural destinations and dynamic sustainable thresholds over time. Sustainability 10(12):4788. https://doi.org/10.3390/su10124788

Hausmann, A., R. Slotow, J. K. Burns, and E. Di Minin. 2016. The ecosystem service of sense of place: benefits for human wellbeing and biodiversity conservation. Environmental Conservation 43(2):117-127. https://doi.org/10.1017/S0376892915000314

Ho, L. T., and P. L. M. Goethals. 2019. Opportunities and challenges for the sustainability of lakes and reservoirs in relation to the Sustainable Development Goals (SDGs). Water 11(7):1462. https://doi.org/10.3390/w11071462

Hogeboom, R. J., L. Knook, and A. Y. Hoekstra. 2018. The blue water footprint of the world's artificial reservoirs for hydroelectricity, irrigation, residential and industrial water supply, flood protection, fishing and recreation. Advances in Water Resources 113:285-294. https://doi.org/10.1016/j.

advwatres.2018.01.028 
Hossu, C. A., I. C. Iojă, D. A. Onose, M. R. Niţă, A. M. Popa, O. Talabă, and L. Inostroza. 2019. Ecosystem services appreciation of urban lakes in Romania. Synergies and trade-offs between multiple users. Ecosystem Services 37:100937. https:// doi.org/10.1016/j.ecoser.2019.100937

Jurgilevich, A. 2021. Governance modes and epistemologies of future-oriented vulnerability assessments: example of a mixedmethods approach. Futures 128:102717. https://doi.org/10.1016/ j.futures.2021.102717

Kainzinger, S., R. C. Burns, and A. Arnberger. 2015. Whitewater boater and angler conflict, crowding and satisfaction on the North Umpqua River, Oregon. Human Dimensions of Wildlife 20 (6):542-552. https://doi.org/10.1080/10871209.2015.1072757

Kaltenborn, B. P., and T. Bjerke. 2002. Association between environmental value orientations and landscape preferences. Landscape and Urban Planning 59(1):1-11. https://doi. org/10.1016/S0169-2046(01)00243-2

Keeler, B. L., S. A. Wood, S. Polasky, C. Kling, C. T. Filstrup, and J. A. Downing. 2015. Recreational demand for clean water: evidence from geotagged photographs by visitors to lakes. Frontiers in Ecology and the Environment 13:76-81. https://doi. org/10.1890/140124

Kenter, J. O., L. O’Brien, N. Hockley, N. Ravenscroft, I. Fazey, K. N. Irvine, M. S. Reed, M. Christie, E. Brady, R. Bryce, A. Church, N. Cooper, A. Davies, A. Evely, M. Everard, R. Fish, J. A. Fisher, N. Jobstvogt, C. Molloy, J. Orchard-Webb, S. Ranger, M. Ryan, V. Watson, and S. Williams. 2015. What are shared and social values of ecosystems? Ecological Economics 111:86-99. https://doi.org/10.1016/j.ecolecon.2015.01.006

Ko, H., and Y. Son. 2018. Perceptions of cultural ecosystem services in urban green spaces: a case study in Gwacheon, Republic of Korea. Ecological Indicators 91:299-306. https://doi. org/10.1016/j.ecolind.2018.04.006

Kumar, M., and P. Kumar. 2008. Valuation of the ecosystem services: a psycho-cultural perspective. Ecological Economics 64 (4):808-819. https://doi.org/10.1016/j.ecolecon.2007.05.008

Lapointe, M., G. G. Gurney, and G. S. Cumming. 2020. Perceived availability and access limitations to ecosystem service well-being benefits increase in urban areas. Ecology and Society 25(4):32. https://doi.org/10.5751/ES-12012-250432

Mackay, C. M., and M. T. Schmitt. 2019. Do people who feel connected to nature do more to protect it? A meta-analysis. Journal of Environmental Psychology 65:101323. https://doi. org/10.1016/j.jenvp.2019.101323

McDougall, C. W., R. S. Quilliam, N. Hanley, and D. M. Oliver. 2020. Freshwater blue space and population health: an emerging research agenda. Science of the Total Environment 737:140196. https://doi.org/10.1016/j.scitotenv.2020.140196

Moreno-Llorca, R., P. F. Méndez, A. Ros-Candeira, D. AlcarazSegura, L. Santamaría, Á. F. Ramos-Ridao, E. Revilla, F. J. Bonet-García, and A. S. Vaz. 2020. Evaluating tourist profiles and nature-based experiences in biosphere reserves using Flickr: matches and mismatches between online social surveys and photo content analysis. Science of the Total Environment 737:140067. https://doi.org/10.1016/j.scitotenv.2020.140067
Moser, K. A., J. S. Baron, J. Brahney, I. A. Oleksy, J. E. Saros, E. J. Hundey, S. A. Sadro, J. Kopáček, R. Sommaruga, M. J. Kainz, A. L. Strecker, S. Chandra, D. M. Walters, D. L. Preston, N. Michelutti, F. Lepori, S. A. Spaulding, K. R. Christianson, J. M. Melack, and J. P. Smol. 2019. Mountain lakes: eyes on global environmental change. Global and Planetary Change 178:77-95. https://doi.org/10.1016/j.gloplacha.2019.04.001

Moyle, B., and G. Croy. 2007. Crowding and visitor satisfaction during the off-season: Port Campbell National Park. Annals of Leisure Research 10(3-4):518-531. https://doi.org/10.1080/1174$\underline{5398.2007 .9686779}$

Muhar, A., C. M. Raymond, R. J. G. van den Born, N. Bauer, K. Böck, M. Braito, A. Buijs, C. Flint, W. T. de Groot, C. D. Ives, T. Mitrofanenko, T. Plieninger, C. Tucker, and C. J. van Riper. 2018. A model integrating social-cultural concepts of nature into frameworks of interaction between social and natural systems. Journal of Environmental Planning and Management 61 (5-6):756-777. https://doi.org/10.1080/09640568.2017.1327424

Nowak-Olejnik, A., E. Mocior, J. Hibner, and N. Tokarczyk. 2020. Human perceptions of cultural ecosystem services of seminatural grasslands: the influence of plant communities. Ecosystem Services 46:101208. https://doi.org/10.1016/j.ecoser.2020.101208

Oliver, R. L. 1980. A cognitive model of the antecedents and consequences of satisfaction decisions. Journal of Marketing Research 17(4):460-469. https://doi.org/10.1177/002224378001700405

Oteros-Rozas, E., B. Martín-López, N. Fagerholm, C. Bieling, and T. Plieninger. 2018. Using social media photos to explore the relation between cultural ecosystem services and landscape features across five European sites. Ecological Indicators 94:74-86. https://doi.org/10.1016/j.ecolind.2017.02.009

Plieninger, T., C. Bieling, N. Fagerholm, A. Byg, T. Hartel, P. Hurley, C. A. López-Santiago, N. Nagabhatla, E. Oteros-Rozas, C. M. Raymond, D. van der Horst, and L. Huntsinger. 2015. The role of cultural ecosystem services in landscape management and planning. Current Opinion in Environmental Sustainability 14:28-33. https://doi.org/10.1016/j.cosust.2015.02.006

Plieninger, T., S. Dijks, E. Oteros-Rozas, and C. Bieling. 2013. Assessing, mapping, and quantifying cultural ecosystem services at community level. Land Use Policy 33:118-129. https://doi. org/10.1016/j.landusepol.2012.12.013

Pröbstl-Haider, U., C. Hödl, K. Ginner, and F. Borgwardt. 2021. Climate change: impacts on outdoor activities in the summer and shoulder seasons. Journal of Outdoor Recreation and Tourism 34:100344. https://doi.org/10.1016/j.jort.2020.100344

Quintas-Soriano, C., J. S. Brandt, K. Running, C. V. Baxter, D. M. Gibson, J. Narducci, and A. J. Castro. 2018. Social-ecological systems influence ecosystem service perception: a programme on ecosystem change and society (PECS) analysis. Ecology and Society 23(3):3. https://doi.org/10.5751/ES-10226-230303

R Core Development Team. 2019. R: A language and environment for statistical computing. The $\mathrm{R}$ Project for Statistical Computing, Vienna, Austria. 
Rall, E., C. Bieling, S. Zytynska, and D. Haase. 2017. Exploring city-wide patterns of cultural ecosystem service perceptions and use. Ecological Indicators 77:80-95. https://doi.org/10.1016/j. ecolind.2017.02.001

Reynaud, A., and D. Lanzanova. 2017. A global meta-analysis of the value of ecosystem services provided by lakes. Ecological Economics 137:184-194. https://doi.org/10.1016/j.ecolecon.2017.03.001

Riechers, M., J. Barkmann, and T. Tscharntke. 2018. Diverging perceptions by social groups on cultural ecosystem services provided by urban green. Landscape and Urban Planning 175:161-168. https://doi.org/10.1016/j.landurbplan.2018.03.017

Roux, D. J., M. K. S. Smith, I. P. J. Smit, S. Freitag, L. Slabbert, M. M. Mokhatla, J. Hayes, and N. P. Mpapane. 2020. Cultural ecosystem services as complex outcomes of people-nature interactions in protected areas. Ecosystem Services 43:101111. https://doi.org/10.1016/j.ecoser.2020.101111

Russell, R., A. D. Guerry, P. Balvanera, R. K. Gould, X. Basurto, K. M. A. Chan, S. Klain, J. Levine, and J. Tam. 2013. Humans and nature: how knowing and experiencing nature affect wellbeing. Annual Review of Environment and Resources 38 (1):473-502. https://doi.org/10.1146/annurev-environ-012312-110838

Sadro, S., J. M. Melack, J. O. Sickman, and K. Skeen. 2019. Climate warming response of mountain lakes affected by variations in snow. Limnology and Oceanography Letters 4 (1):9-17. https://doi.org/10.1002/1o12.10099

Sayadi, S., M. C. González-Roa, and J. Calatrava-Requena. 2009. Public preferences for landscape features: the case of agricultural landscape in mountainous Mediterranean areas. Land Use Policy 26(2):334-344. https://doi.org/10.1016/j.landusepol.2008.04.003

Schirpke, U., S. Candiago, L. Egarter Vigl, H. Jäger, A. Labadini, T. Marsoner, C. Meisch, E. Tasser, and U. Tappeiner. 2019. Integrating supply, flow and demand to enhance the understanding of interactions among multiple ecosystem services. Science of the Total Environment 651:928-941. https:// doi.org/10.1016/j.scitotenv.2018.09.235

Schirpke, U., R. Scolozzi, R. Da Re, M. Masiero, D. Pellegrino, and D. Marino. 2018. Recreational ecosystem services in protected areas: a survey of visitors to Natura 2000 sites in Italy. Journal of Outdoor Recreation and Tourism 21:39-50. https:// doi.org/10.1016/j.jort.2018.01.003

Schirpke, U., R. Scolozzi, G. Dean, A. Haller, H. Jäger, J. Kister, B. Kovács, F. O. Sarmiento, B. Sattler, and C. Schleyer. 2020. Cultural ecosystem services in mountain regions: conceptualising conflicts among users and limitations of use. Ecosystem Services 46:101210. https://doi.org/10.1016/j.ecoser.2020.101210

Schirpke, U., R. Scolozzi, A. Kiessling, and U. Tappeiner. 2021 b. Recreational ecosystem services of mountain lakes in the European Alps: preferences, visitor groups and management implications. Journal of Outdoor Recreation and Tourism 35:100421. https://doi.org/10.1016/j.jort.2021.100421

Schirpke, U., E. Tasser, M. Ebner, and U. Tappeiner. 2021a. What can geotagged photographs tell us on cultural ecosystem services of lakes? Ecosystem Services 51:101354. https://doi.org/10.1016/ j.ecoser.2021.101354
Schmeller, D. S., A. Loyau, K. Bao, W. Brack, A. Chatzinotas, F. De Vleeschouwer, J. Friesen, L. Gandois, S. V. Hansson, M. Haver, G. Le Roux, J. Shen, R. Teisserenc, and V. T. Vredenburg. 2018. People, pollution and pathogens - global change impacts in mountain freshwater ecosystems. Science of the Total Environment 622-623:756-763. https://doi.org/10.1016/j. scitotenv.2017.12.006

Scolozzi, R., U. Schirpke, C. Detassis, S. Abdullah, and A. Gretter. 2015. Mapping alpine landscape values and related threats as perceived by tourists. Landscape Research 40 (4):451-465. https://doi.org/10.1080/01426397.2014.902921

Senetra, A., P. Dynowski, I. Cieślak, and A. Źróbek-Sokolnik. 2020. An evaluation of the impact of hiking tourism on the ecological status of alpine lakes - a case study of the Valley of Dolina Pięciu Stawów Polskich in the Tatra Mountains. Sustainability 12:2963. https://doi.org/10.3390/su12072963

Small, N., M. Munday, and I. Durance. 2017. The challenge of valuing ecosystem services that have no material benefits. Global Environmental Change 44:57-67. https://doi.org/10.1016/j. gloenvcha.2017.03.005

Soliva, R., J. Bolliger, and M. Hunziker. 2010. Differences in preferences towards potential future landscapes in the Swiss Alps. Landscape Research 35(6):671-696. https://doi.org/10.1080/01426397.2010.519436

Sterner, R. W., B. Keeler, S. Polasky, R. Poudel, K. Rhude, and M. Rogers. 2020. Ecosystem services of Earth's largest freshwater lakes. Ecosystem Services 41:101046. https://doi.org/10.1016/j. ecoser.2019.101046

Van Berkel, D. B., and P. H. Verburg. 2014. Spatial quantification and valuation of cultural ecosystem services in an agricultural landscape. Ecological Indicators 37(Part A):163-174. https://doi. org/10.1016/j.ecolind.2012.06.025

Van Colen, W., P. V. Mosquera, H. Hampel, and K. Muylaert. 2018. Link between cattle and the trophic status of tropical high mountain lakes in páramo grasslands in Ecuador. Lakes \& Reservoirs: Science, Policy and Management for Sustainable Use 23(4):303-311. https://doi.org/10.1111/1re.12237

van Zanten, B. T., I. Zasada, M. J. Koetse, F. Ungaro, K. Häfner, and P. H. Verburg. 2016. A comparative approach to assess the contribution of landscape features to aesthetic and recreational values in agricultural landscapes. Ecosystem Services 17:87-98. https://doi.org/10.1016/j.ecoser.2015.11.011

Völker, S., and T. Kistemann. 2011. The impact of blue space on human health and well-being - salutogenetic health effects of inland surface waters: a review. International Journal of Hygiene and Environmental Health 214(6):449-460. https://doi. org/10.1016/j.ijheh.2011.05.001

Wartmann, F. M., and R. S. Purves. 2018. Investigating sense of place as a cultural ecosystem service in different landscapes through the lens of language. Landscape and Urban Planning 175:169-183. https://doi.org/10.1016/j.landurbplan.2018.03.021

Wen, J., C. C. Wang, and M. Kozak. 2021. Post-COVID-19 Chinese domestic tourism market recovery: potential influence of traditional Chinese medicine on tourist behaviour. Anatolia 32(1)121-125. https://doi.org/10.1080/13032917.2020.1768335 
White, M. P., S. Pahl, K. Ashbullby, S. Herbert, and M. H. Depledge. 2013. Feelings of restoration from recent nature visits. Journal of Environmental Psychology 35:40-51. https://doi. org/10.1016/j.jenvp.2013.04.002

Zehrer, A., and F. Raich. 2016. The impact of perceived crowding on customer satisfaction. Journal of Hospitality and Tourism Management 29:88-98. https://doi.org/10.1016/j.jhtm.2016.06.007

Zoderer, B. M., P. S. Lupo Stanghellini, E. Tasser, J. Walde, H. Wieser, and U. Tappeiner. 2016b. Exploring socio-cultural values of ecosystem service categories in the Central Alps: the influence of socio-demographic factors and landscape type. Regional Environmental Change 16(7):2033-2044. https://doi.org/10.1007/ $\underline{\text { s10113-015-0922-y }}$

Zoderer, B. M., E. Tasser, K.-H. Erb, P. S. Lupo Stanghellini, and U. Tappeiner. 2016a. Identifying and mapping the tourists' perception of cultural ecosystem services: a case study from an Alpine region. Land Use Policy 56:251-261. https://doi. org/10.1016/j.landusepol.2016.05.004 


\section{APPENDIX 1}

\section{QUESTIONNAIRE}

\section{MOUNTAIN LAKES IN THE ALPS}

\section{Section 1}

The questionnaire below is composed of questions about your perception of mountain lakes. These are smallersized natural lakes, which are located at least 1000 meters above sea level. To complete this questionnaire will take you approximately 10-15 minutes.

Within each section, please choose the most appropriate option for you.

The participation is voluntary and anonymous. You can withdraw at any time. All data will be treated confidentially and not be passed on to third parties.

Please find further information about this project at: https://www.uibk.ac.at/projects/claimes/index.html.de

* required

Consent of voluntary participation *

$\square$ I hereby confirm my voluntary participation 


\section{Section 2}

What are mountain lakes particularly suitable for? How accurate are the following statements in your opinion? Mountain lakes are suitable... *

$\begin{array}{ccccc}\begin{array}{c}\text { does not } \\ \text { apply at all }\end{array} & \begin{array}{c}\text { does not } \\ \text { really apply }\end{array} & \begin{array}{c}\text { somewhat } \\ \text { applies }\end{array} & \begin{array}{c}\text { definitely } \\ \text { applies }\end{array} & \text { don't know } \\ 0 & 0 & 0 & 0 & 0 \\ 0 & 0 & 0 & 0 & 0 \\ 0 & 0 & 0 & 0 & 0 \\ 0 & 0 & 0 & 0 & 0 \\ 0 & 0 & 0 & 0 & 0\end{array}$

Thinking of mountain lakes, which of the following statements are more or less accurate for you? Mountain lakes are ... *

essential elements of alpine landscapes

places with symbolic power

places of spirituality

places of great aesthetic value

worth preserving in their natural state

places that convey a sense of home, of belonging

$\begin{array}{ccccc}\begin{array}{c}\text { does not } \\ \text { apply at all }\end{array} & \begin{array}{c}\text { does not } \\ \text { really apply }\end{array} & \begin{array}{c}\text { somewhat } \\ \text { applies }\end{array} & \begin{array}{c}\text { definitely } \\ \text { applies }\end{array} & \text { don't know } \\ 0 & 0 & 0 & 0 & 0 \\ 0 & 0 & 0 & 0 & 0 \\ 0 & 0 & 0 & 0 & 0 \\ 0 & 0 & 0 & 0 & 0 \\ 0 & 0 & 0 & 0 & 0 \\ 0 & 0 & 0 & 0 & 0\end{array}$




\section{Section 3}

Have a look at the picture. Imagine that you have arrived at this mountain lake and take a short rest.

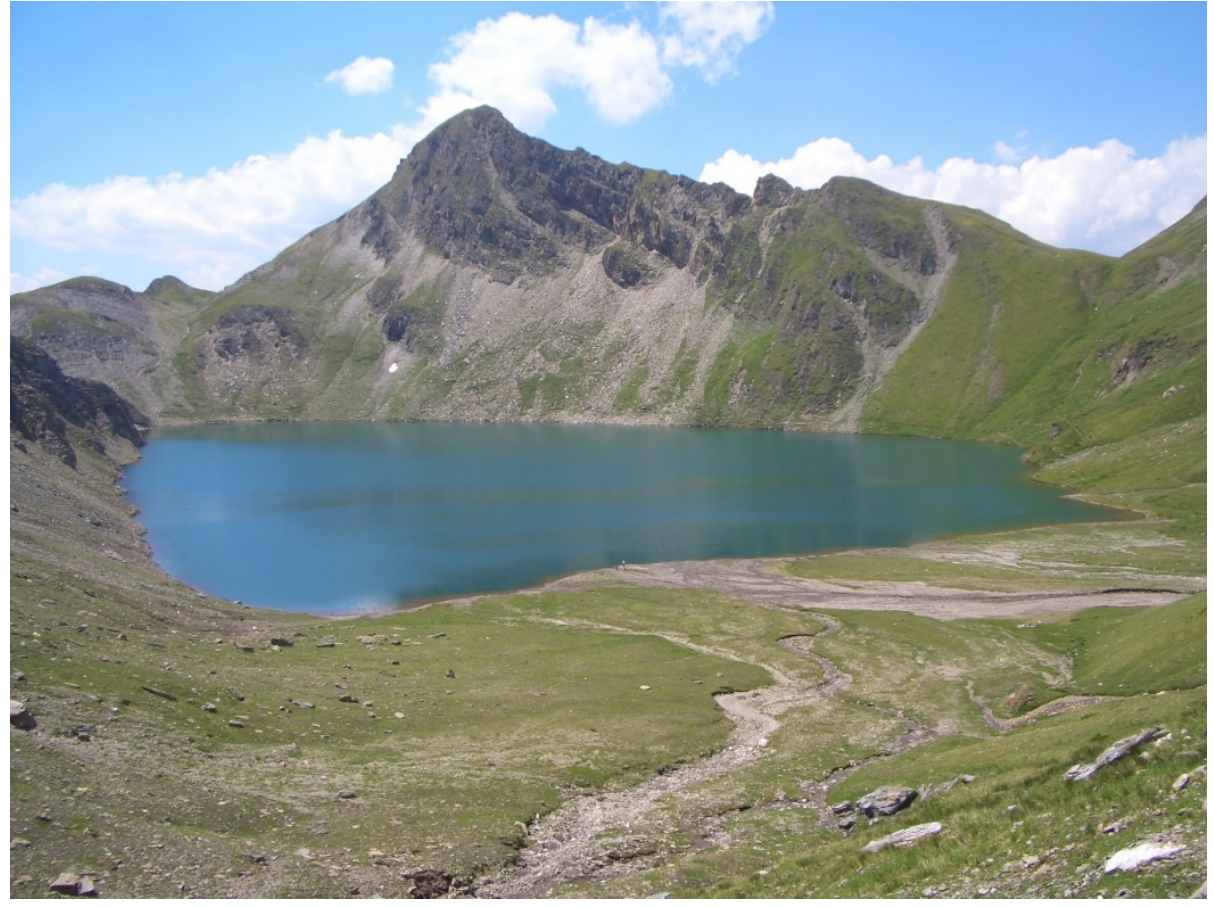

How accurate are the following statements for you?

Visiting a place like this leaves me with the feeling that I have learned something from nature *

$\begin{array}{lllllll} & 1 & 2 & 3 & 4 & 5 & \\ \text { does not apply at all } & 0 & 0 & \bigcirc & \bigcirc & \bigcirc & \text { definitely applies }\end{array}$

Having spent time at a place like this, I feel healthier *

$\begin{array}{lllllll} & 1 & 2 & 3 & 4 & 5 & \\ \text { does not apply at all } & 0 & 0 & 0 & 0 & 0 & \text { definitely applies }\end{array}$

Visiting a place like this leaves me with lasting memories *

$\begin{array}{lllllll} & 1 & 2 & 3 & 4 & 5 & \\ \text { does not apply at all } & 0 & \bigcirc & \bigcirc & \bigcirc & \bigcirc & \text { definitely applies }\end{array}$

In a place like this, I feel excited *

$\begin{array}{lllllll} & 1 & 2 & 3 & 4 & 5 & \\ \text { does not apply at all } & 0 & 0 & \bigcirc & \bigcirc & \bigcirc & \text { definitely applies }\end{array}$


A place like this makes me feel at home *

$\begin{array}{lllllll} & 1 & 2 & 3 & 4 & 5 & \\ \text { does not apply at all } & 0 & 0 & \bigcirc & \bigcirc & \bigcirc & \text { definitely applies }\end{array}$

Visiting a place like this gives me a sense of freedom *

$\begin{array}{lllllll} & 1 & 2 & 3 & 4 & 5 & \\ \text { does not apply at all } & 0 & 0 & 0 & \bigcirc & 0 & \text { definitely applies }\end{array}$

In a place like this, I feel in touch with nature *

$\begin{array}{lllllll} & 1 & 2 & 3 & 4 & 5 & \\ \text { does not apply at all } & 0 & 0 & \bigcirc & \bigcirc & 0 & \text { definitely applies }\end{array}$

A place like this instills inner peace within me *

$\begin{array}{lllllll} & 1 & 2 & 3 & 4 & 5 & \\ \text { does not apply at all } & 0 & 0 & 0 & 0 & 0 & \text { definitely applies }\end{array}$

This is a place to refresh and cool down on particularly hot days *

$\begin{array}{lllllll} & 1 & 2 & 3 & 4 & 5 & \\ \text { does not apply at all } & 0 & 0 & 0 & 0 & 0 & \text { definitely applies }\end{array}$

Having visited a place like this, I feel more relaxed *

$\begin{array}{lllllll} & 1 & 2 & 3 & 4 & 5 & \\ \text { does not apply at all } & 0 & 0 & 0 & 0 & 0 & \text { definitely applies }\end{array}$

In a place like this, I find inspiration *

$\begin{array}{lllllll} & 1 & 2 & 3 & 4 & 5 & \\ \text { does not apply at all } & 0 & 0 & \bigcirc & \bigcirc & 0 & \text { definitely applies }\end{array}$




\section{Section 4}

You are visiting a mountain lake. In your opinion, what could diminish your experience of this visit and discourage you from extending your stay? Please, briefly describe this in a few words. * 


\section{Section 5}

Concluding this survey, we would like to ask you for some personal data. Providing this information is voluntary. We wish to reiterate that all data is treated confidentially and will not be passed on to third parties.
Gender
Female
O Male
$\mathrm{OX}$

In which year were you born?

How frequently do you spend time in nature?
Every day
Several times a week
Several times a month
Once a month
$\mathrm{O}$ Less than once a month

On average, how often do you visit mountain lakes a year?
never
occasionally (1 - 3 times)
often (4 - 10 times)
$\bigcirc$ frequently (more than 10 times)

How do you relate to the Alpine region?
I live in the Alpine region, where I also grew up
$O$ I live in the Alpine region, but I did not grow up there
I live outside of the Alpine region and visit it primarily as a tourist
I grew up in the Alps, but now I live somewhere else
I mainly travel to the Alpine region for professional purposes
$\mathrm{O}$ I have no connection to the Alpine region 


\section{APPENDIX 2}
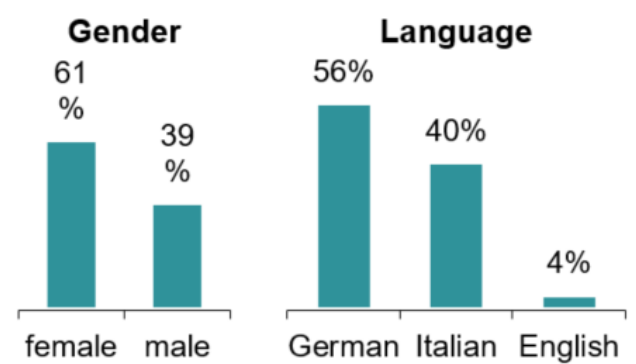

Age

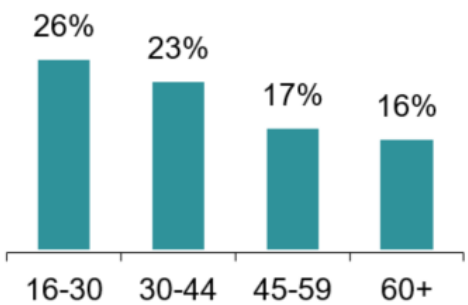

How frequently do you spend time in nature?

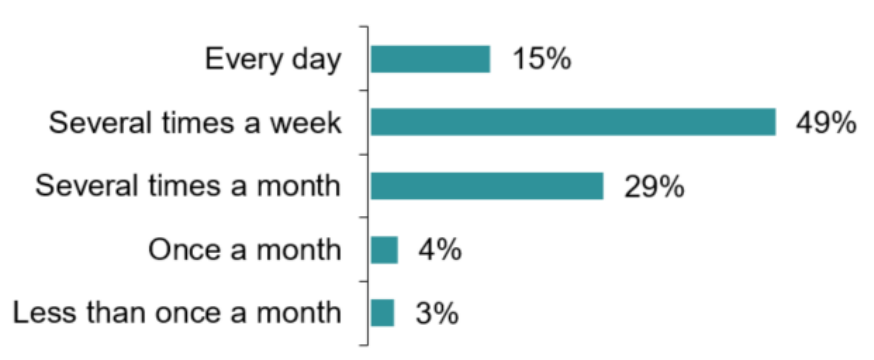

How often do you visit mountain lakes a year?

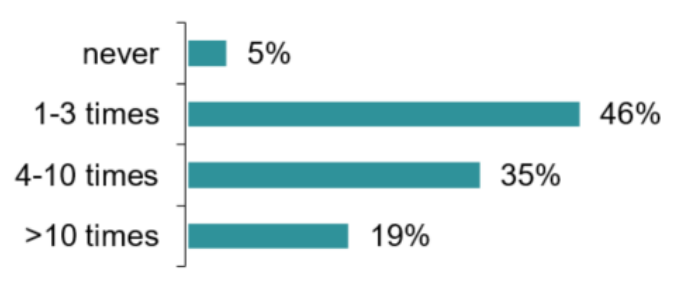

How do you relate to the Alpine region?

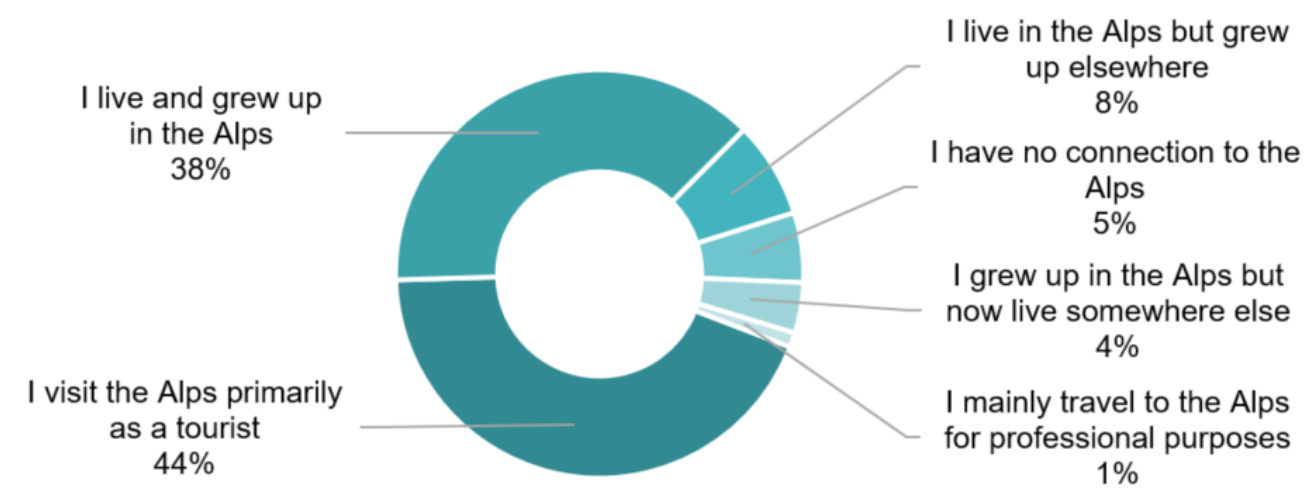

Fig. A.2.1: Characteristics of the respondents $(n=526)$. 
Table A.2.1: Perceived value of CES of mountain lakes (in descending order) and mean values of socio-cultural groups. Statistically significant differences between groups are indicated by * $(\mathrm{p}<0.01)$ and $* *(\mathrm{p}<0.001)$.

\begin{tabular}{|c|c|c|c|c|c|c|c|c|c|c|c|c|c|}
\hline & \multirow{3}{*}{$\begin{array}{l}\text { Total } \\
N=526\end{array}$} & \multirow{2}{*}{$\begin{array}{l}\text { Gender } \\
\text { Female }\end{array}$} & \multirow{3}{*}{$\begin{array}{l}\text { Male } \\
N=201\end{array}$} & \multicolumn{2}{|l|}{ Age } & \multicolumn{2}{|c|}{ Cultural background } & \multicolumn{2}{|c|}{ Relation to Alps } & \multicolumn{2}{|c|}{ Frequency of visits in nature } & \multicolumn{2}{|c|}{ Lake affinity } \\
\hline & & & & $<40$ & $40+$ & German & Italian & Residents & Tourists & Low & High & Low & High \\
\hline & & $N=320$ & & $N=253$ & $N=256$ & $N=294$ & $N=210$ & $N=199$ & $N=229$ & $N=187$ & $N=335$ & $N=255$ & $N=268$ \\
\hline Bequest value & 2.825 & 2.825 & 2.826 & 2.806 & 2.852 & 2.779 & 2.881 & 2.824 & 2.852 & 2.834 & 2.821 & 2.824 & 2.828 \\
\hline Symbolic value & 2.587 & 2.641 & 2.502 & 2.585 & 2.586 & $2.799 * *$ & $2.343^{* *}$ & 2.613 & 2.611 & 2.487 & 2.639 & 2.627 & 2.545 \\
\hline Aesthetic value & 2.521 & 2.553 & 2.463 & 2.510 & 2.539 & $2.408^{*}$ & $2.638^{*}$ & 2.613 & 2.524 & 2.535 & 2.507 & 2.459 & 2.578 \\
\hline Education & 2.500 & 2.516 & 2.478 & 2.494 & 2.496 & $2.354^{* *}$ & $2.690 * *$ & 2.457 & 2.507 & 2.594 & 2.442 & 2.518 & 2.478 \\
\hline Spiritual value & 2.494 & 2.559 & 2.388 & 2.443 & 2.535 & $2.694^{* *}$ & $2.248 * *$ & 2.477 & 2.498 & 2.417 & 2.531 & 2.545 & 2.440 \\
\hline Existence value & 2.492 & 2.475 & 2.527 & 2.486 & 2.516 & $2.180^{* *}$ & $2.876^{* *}$ & 2.643 & 2.445 & 2.561 & 2.454 & $2.369 * *$ & $2.616^{* *}$ \\
\hline Outdoor recreation & 2.158 & 2.159 & 2.149 & 2.213 & 2.090 & 2.204 & 2.133 & 2.090 & 2.170 & 2.257 & 2.099 & $2.302 * *$ & $2.015^{* *}$ \\
\hline Sense of place & 2.076 & $2.184^{*}$ & $1.900 *$ & 2.008 & 2.141 & $1.952 * *$ & $2.271^{* *}$ & 2.241 & 2.070 & 2.032 & 2.093 & 1.976 & 2.168 \\
\hline Scientific research & 1.795 & 1.769 & 1.856 & 1.806 & 1.793 & $1.224^{* *}$ & $2.510^{* *}$ & 1.819 & 1.812 & $2.005^{* *}$ & $1.675^{* *}$ & 1.765 & 1.836 \\
\hline Representation & 1.534 & $1.441^{*}$ & $1.692 *$ & $1.660^{*}$ & $1.410^{*}$ & 1.599 & 1.467 & 1.608 & 1.428 & 1.529 & 1.534 & 1.498 & 1.575 \\
\hline Entertainment & 1.430 & 1.416 & 1.468 & 1.455 & 1.406 & 1.364 & 1.505 & 1.528 & 1.393 & 1.503 & 1.391 & 1.459 & 1.410 \\
\hline
\end{tabular}


Table A.2.2: Perceived value of experiences of mountain lakes (in descending order) and mean values of socio-cultural groups. Statistically significant differences between groups are indicated by * $(\mathrm{p}<0.01)$ and $* *(\mathrm{p}<0.001)$.

\begin{tabular}{|c|c|c|c|c|c|c|c|c|c|c|c|c|c|}
\hline & \multirow{3}{*}{$\begin{array}{l}\text { Total } \\
N=526\end{array}$} & \multirow{2}{*}{$\begin{array}{l}\text { Gender } \\
\text { Female }\end{array}$} & \multirow{3}{*}{$\begin{array}{l}\text { Male } \\
N=201\end{array}$} & \multicolumn{2}{|l|}{ Age } & \multicolumn{2}{|c|}{ Cultural background } & \multicolumn{2}{|c|}{ Relation to Alps } & \multicolumn{2}{|c|}{ Frequency of visits in nature } & \multicolumn{2}{|c|}{ Lake affinity } \\
\hline & & & & $<40$ & $40+$ & German & Italian & Residents & Tourists & Low & High & Low & High \\
\hline & & $N=320$ & & $N=253$ & $N=256$ & $N=294$ & $N=210$ & $N=199$ & $N=229$ & $N=187$ & $N=335$ & $N=255$ & $N=268$ \\
\hline Connection to nature & 2.605 & $2.716^{* *}$ & $2.458^{* *}$ & 2.557 & 2.676 & 2.527 & 2.695 & 2.603 & 2.668 & 2.578 & 2.621 & $2.569 *$ & $2.642 *$ \\
\hline Relaxation & 2.544 & $2.644^{* *}$ & $2.398^{* *}$ & 2.549 & 2.566 & 2.503 & 2.576 & 2.523 & 2.616 & 2.545 & 2.546 & 2.510 & 2.582 \\
\hline Freedom & 2.542 & 2.622 & 2.443 & 2.625 & 2.516 & $2.425^{* *}$ & $2.686^{* *}$ & 2.618 & 2.511 & 2.519 & 2.558 & $2.384 * *$ & $2.687^{* *}$ \\
\hline Peace & 2.371 & $2.509 * *$ & $2.169 * *$ & 2.356 & 2.410 & $2.483^{* *}$ & $2.176^{* *}$ & 2.397 & 2.402 & 2.262 & 2.433 & 2.329 & 2.403 \\
\hline Memories & 2.365 & $2.484^{* *}$ & $2.189 * *$ & 2.364 & 2.387 & $2.510^{* *}$ & $2.171^{* *}$ & 2.357 & 2.371 & $2.198 *$ & $2.454 *$ & 2.341 & 2.381 \\
\hline Health & 2.169 & $2.294 *$ & $1.990 *$ & 2.249 & 2.145 & 2.075 & 2.271 & 2.231 & 2.175 & 2.267 & 2.116 & 2.078 & 2.25 \\
\hline Inspiration & 1.943 & $2.075^{* *}$ & $1.716^{* *}$ & 1.874 & 2.023 & 1.854 & 2.038 & 1.95 & 1.974 & 1.904 & 1.955 & 1.867 & 2.015 \\
\hline Excitement & 1.897 & $2.094 * *$ & $1.607^{* *}$ & 1.929 & 1.930 & $1.663^{* *}$ & $2.205^{* *}$ & 1.824 & 1.952 & 1.941 & 1.875 & 1.784 & 2.004 \\
\hline Sense of belonging & 1.835 & 1.913 & 1.736 & 1.913 & 1.801 & $1.748^{*}$ & $2.005^{*}$ & $2.221^{* *}$ & $1.555^{* *}$ & $1.583 * *$ & $1.973 * *$ & $1.424 * *$ & $2.228 * *$ \\
\hline Refreshment & 1.783 & 1.806 & 1.761 & 1.775 & 1.805 & 1.905 & 1.657 & 1.688 & 1.843 & 1.727 & 1.818 & 1.851 & 1.728 \\
\hline Life lessons & 1.721 & 1.741 & 1.711 & 1.617 & 1.844 & $1.500 * *$ & $2.038 * *$ & 1.683 & 1.803 & 1.733 & 1.704 & 1.616 & 1.813 \\
\hline
\end{tabular}

Table A.2.3: Pressures mentioned in relation to a visit to mountain lakes (in descending order) and mean values of socio-cultural groups. Statistically significant differences between groups are indicated by $*(p<0.01)$ and $* *(p<0.001)$.

\begin{tabular}{|c|c|c|c|c|c|c|c|c|c|c|c|c|c|}
\hline & \multirow{3}{*}{$\begin{array}{l}\text { Total } \\
N=526\end{array}$} & \multirow{2}{*}{$\begin{array}{l}\text { Gender } \\
\text { Female }\end{array}$} & \multirow{3}{*}{$\begin{array}{l}\text { Male } \\
N=201\end{array}$} & \multicolumn{2}{|l|}{ Age } & \multicolumn{2}{|c|}{ Cultural background } & \multicolumn{2}{|c|}{ Relation to Alps } & \multicolumn{2}{|c|}{ Frequency of visits in nature } & \multicolumn{2}{|c|}{ Lake affinity } \\
\hline & & & & $<40$ & $40+$ & German & Italian & Residents & Tourists & Low & High & Low & High \\
\hline & & $N=320$ & & $N=253$ & $N=256$ & $N=294$ & $N=210$ & $N=199$ & $N=229$ & $N=187$ & $N=335$ & $N=255$ & $N=268$ \\
\hline Crowdedness & 0.700 & 0.691 & 0.716 & 0.719 & 0.676 & 0.738 & 0.643 & 0.693 & 0.707 & 0.701 & 0.701 & 0.694 & 0.705 \\
\hline Noisiness & 0.272 & $0.313^{*}$ & $0.209 *$ & 0.269 & 0.273 & $0.350 * *$ & $0.162 * *$ & 0.286 & 0.249 & 0.262 & 0.278 & 0.267 & 0.276 \\
\hline Garbage/pollution & 0.213 & 0.231 & 0.184 & $0.289 * *$ & $0.148^{* *}$ & $0.269 * *$ & $0.124^{* *}$ & 0.191 & 0.223 & 0.198 & 0.224 & 0.235 & 0.190 \\
\hline Touristic exploitation & 0.186 & 0.159 & 0.234 & 0.225 & 0.156 & $0.269 * *$ & $0.081 * *$ & 0.181 & 0.170 & 0.198 & 0.182 & 0.212 & 0.164 \\
\hline Bad weather & 0.120 & 0.138 & 0.095 & 0.103 & 0.141 & 0.105 & 0.138 & 0.131 & 0.140 & 0.123 & 0.119 & 0.122 & 0.119 \\
\hline Anthropization & 0.118 & 0.113 & 0.129 & 0.154 & 0.086 & 0.136 & 0.095 & 0.121 & 0.096 & 0.112 & 0.119 & 0.125 & 0.108 \\
\hline Other & 0.046 & 0.053 & 0.035 & 0.036 & 0.055 & 0.048 & 0.038 & 0.030 & 0.066 & 0.064 & 0.036 & 0.063 & 0.030 \\
\hline
\end{tabular}




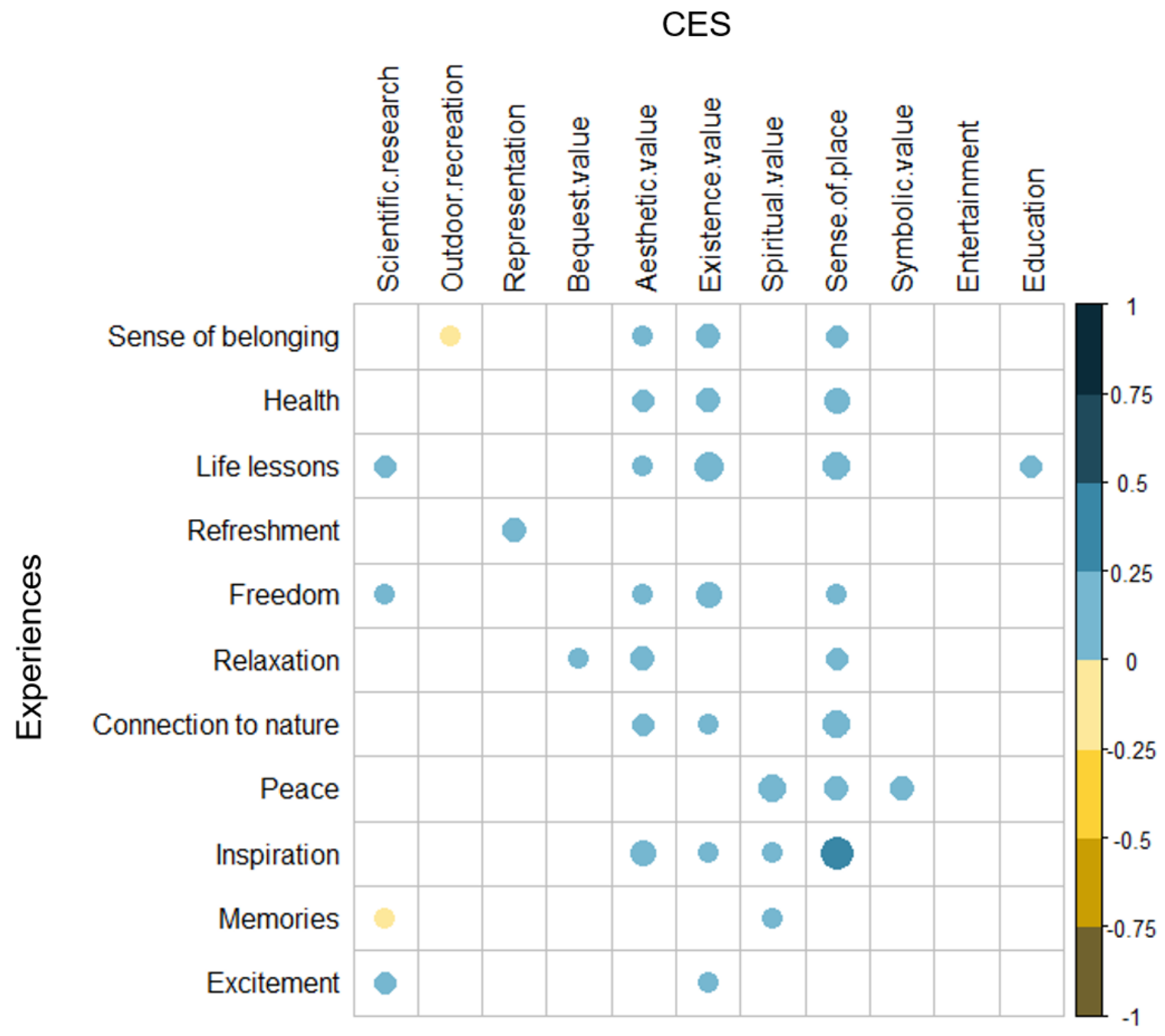

Fig. A.2.2: Correlations between CES and experiences with a significance level of $p \leq 0.01$. Strength shown through Pearson's r coefficient, represented by the size of the circles. Circles with different shades of blue indicate positive correlations and the circles in yellow shades represent negative correlations. 